\title{
A realidade do mercado médico brasileiro
}

\section{The reality of brazilian medical market}

tCbC Jurandir Marcondes Ribas Filho; ECBC Osvaldo Malafaia; tCBC nicolau Gregori Czeczko

A OMS preconiza que para o equilíbrio e satisfação da assistência médica deva existir um médico para cada 1000 habitantes. O Brasil possui hoje aproximadamente 300 mil médicos dos quais 280 mil estão em atividade. A média atual, portanto, é de quase 1.5 médicos por 1000 habitantes. Com essa proporção, ocupamos o primeiro lugar do ranking mundial, sendo ela superior mesmo a da Índia e China.

Este exagero numérico leva à distorções na formação médica e na busca de espaço no mercado de trabaIho, tornando-o por vezes aviltante. A estrutura da assistência médica imposta e posteriormente ratificada pela Constituição Federal cavou um fosso tão abismante na política de saúde em nosso país que conseguiu separar os médicos em duas categorias: os de $1^{\text {a }}$ classe - cujo mercado promissor estará sempre fortalecido pelos poucos ricos e pelos quase ricos; e os de $2^{a}$ classe - destituída de mercado e recebendo honorários médicos aviltantes.

Conforme pesquisa elaborada pelo CFM em 2007, 95,5\% dos médicos brasileiros encontravam-se em atividade, e apenas 4,5\% não exerciam a profissão. Destes, 3,7\% eram aposentados e 0,2\% desempregados. Em relação à idade, um dado que chamou a atenção dentre os números apresentados nesta pesquisa é que somente $50,7 \%$ dos que estavam acima dos 70 anos eram aposentados, confirmando tendência no adiamento da aposentadoria, provavelmente devido ao receio de queda no padrão de vida ao parar de exercer a medicina, justamente na fase mais sensível da sua existência. Este fato repete os achados de pesquisa idêntica realizada também pelo CFM, em 2004.

Em relação ao campo de atuação do médico observa-se, também de forma clara, a queda de atividade em consultório que era de $67 \%$ na anterior, passando para $42,7 \%$ na última pesquisa. Soma-se a isto interessante dado: o trabalho em postos de saúde passou de 14,3\% para $27 \%$, muito provavelmente devido ao crescimento do Programa de Saúde da Família - PSF. Em conjunto, os dados levantados mostram perda da atividade privada com ampliação significativa da dependência do poder público no exercício da medicina em nosso País.

Outro dado também preocupante no cenário da prática médica, diz respeito ao número de atividades exercidas na jornada de trabalho de nossos colegas. Do total em exercício, somente $29 \%$ têm o privilégio de pos- suir apenas uma atividade. Os demais $71 \%$ trabalham em dois ou mais empregos - ainda pior - 19,7\% destes dividem sua jornada de trabalho entre cidades diferentes ampliando, com o tempo perdido no deslocamento, o número diário de horas trabalhadas sem produtividade. Comprometese assim, de maneira inequívoca e clara, a qualidade de vida pessoal e familiar de nossos colegas.

Em relação aos níveis de remuneração, ocorre outra situação de grande preocupação. Hoje apenas $55,7 \%$ dos médicos apresentam renda mensal superior a $\mathrm{R} \$ 7.000,00$ e, dos restantes, 25,2\% recebem mensalmente no máximo $R \$ 4.000,00$, quantia esta que não é compatível com as necessidades mínimas para sustentar uma família em padrão razoável de vida e de crescimento intelectual.

Estes dados mostram de forma clara que o caráter liberal da profissão tem sido alterado significativamente, diminuindo cada vez mais o percentual de atividades autônomas em relação às empregatícias, fracionadas em três ou mais empregos.

Sejam quais forem as razões determinantes, todo e qualquer mercado de trabalho encontra sobrevivência no equilíbrio entre a oferta e a procura. Quando se amplia demais a oferta, ocorre degeneração perigosa no mercado e, aplicando-se esta lei no campo da medicina, prenunciamse reflexos negativos diretos no campo ético.

Sem dúvida, as razões dos problemas relatados por nossas entidades máximas de classe - CFM e AMB - e publicados de formas diferentes em diferentes épocas, apontam sempre na mesma direção: o futuro do exercício da medicina é preocupante. O cerne da questão é a proliferação indiscriminada de escolas médicas. Nos anos 60 eram 29. No final dos anos 90 somavam-se 92 . Hoje o Brasil tem 175 faculdades. Ao número geometricamente aumentado na formação de novos médicos em novas escolas, se soma a permitida ampliação de vagas nos cursos previamente existentes. Em 2008 foram mais 17 mil o total de alunos que ingressaram nos cursos médicos em nosso país. A análise matemática simples destes dados pode dar a dimensão dos problemas que surgirão no mercado de trabalho do médico em futuro muito próximo.

Todas as entidades médicas têm-se manifestado na necessidade de regulamentação rígida para abertura de novos cursos e monitoramento constante dos existentes. Os requisitos mínimos obrigatórios seriam a necessidade 
social do curso, existência na cidade de corpo docente qualificado sem dependência de outros centros para complementá-lo, infra-estrutura com hospital-escola próprio contando com vagas de residência médica em número crescente ao longo dos anos, ampliando com ela a formação profissional de melhor qualidade. Evitar-se-ia assim que grupos aventureiros, por interesses não dignos, procurem criar cursos de medicina achando que o tempo acomodará as falhas iniciais, pensando mentirosamente que criar hospital-escola é tarefa fácil e encontrável em qualquer esquina! Estes e outros critérios, aliás, fazem parte do PL 65/03, já aprovado na Comissão de Educação e Cultura e na Comissão de Constituição e Justiça da Câmara dos Deputados, devendo em breve ser aprovado no Plenário.

Esta preocupação não é corporativa, mas sim ela procura estar em defesa da qualidade do atendimento médico à população brasileira. Este também é o anseio da própria população que espera ter maior profissionalismo no atendimento e ver o melhor da tecnologia médica ser aplicado à sua doença. Da forma como o cenário está posto, as perspectivas futuras não são nada alvissareiras. Já no presente - e com piora do quadro em futuro bem próximo -, o Brasil possui número de médicos muito acima do necessário. Este fato negativo gera outros, também negativos: empobrecimento da classe; piora na qualidade de vida do médico; maiores dificuldades de atualização profissional; sobrecarga de trabalho para sobreviver com a dignidade que a profissão impõe; disputas não éticas na busca de espaço dentro da profissão. A resultante final, também negativa, atingirá a população brasileira que nada tem a ver com isso, pois não pode decidir pelas mudanças, e é a que mais sofrerá com este quadro. Não é justo!

Devemos todos nós médicos juntos erguer a voz, falarmos em uníssono e em bom tom e convencermos nossos legisladores do perigo que está sobre todos nós, se não mudarmos de rumo a estrada que está nos levando ao abismo!

Endereço para correspondência:

Jurandir Marcondes Ribas

Al. Augusto Stellfeld, 1980 - Bigorrilho

80730-150 - Curitiba - PR 